\title{
Modified High Back-Pressure Heating System Integrated with Raw Coal Pre-Drying in Combined Heat and Power Unit
}

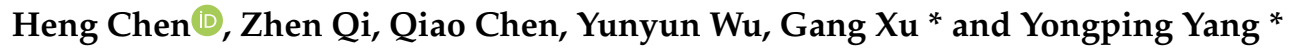 \\ National Thermal Power Engineering and Technology Research Center, North China Electric Power University, \\ Beijing 102206, China; heng@ncepu.edu.cn (H.C.); qizhenhdnd@163.com (Z.Q.); \\ jasonchen1227@foxmail.com (Q.C.); 18813003820@163.com (Y.W.) \\ * Correspondence: xgncepu@163.com (G.X.); yyp@ncepu.edu.cn (Y.Y.); Tel.: +86-(10)-6177-2472 (G.X.); \\ +86-(10)-6177-2002 (Y.Y.)
}

Received: 21 August 2018; Accepted: 17 September 2018; Published: 19 September 2018

check for updates

\begin{abstract}
A conceptual high-back pressure (HBP) heating system cooperating raw coal pre-drying for combined heat and power (CHP) was proposed to improve the performance of the HBP-CHP unit. In the new design, besides of heating the supply-water of the heating network, a portion of the exhaust steam from the turbine is employed to desiccate the raw coal prior to the coal pulverizer, which further recovers the waste heat of the exhaust steam and contributes to raising the overall efficiency of the unit. Thermodynamic and economic analyzes were conducted based on a typical $300 \mathrm{MW}$ coal-fired HBP-CHP unit with the application of the modified configuration. The results showed that the power generation thermal efficiency promotion of the unit reaches $1.7 \%$ (absolute value) owing to suggested retrofitting, and meanwhile, the power generation standard coal consumption rate is diminished by $5.8 \mathrm{~g} / \mathrm{kWh}$. Due to the raw coal pre-drying, the energy loss of the exhaust flue gas of the boiler is reduced by $19.1 \%$ and the boiler efficiency increases from $92.7 \%$ to $95.4 \%$. The impacts of the water content of the dried coal and the unit heating capacity on the energy-saving effect of the new concept were also examined.
\end{abstract}

Keywords: high back-pressure heating; coal pre-drying; combined heat and power; waste energy recovery; exhaust steam

\section{Introduction}

Nowadays, human society is facing serious energy and environment problems, one of which is the swift growth of greenhouse gas (GHG) emissions, contributing to the global climate change $[1,2]$. Combined heat and power (CHP) cogeneration technology is mature and well proven, and is expected to play a significant role in cutting down GHG emissions, which is the simultaneous generation of electricity and heat from a primary fuel such as natural gas or coal [3-6]. By centralizing and combining heat and electricity production in a cogeneration unit, the overall energy efficiency may exceed $90 \%$, but the energy efficiency of a typical power generation unit is usually less than $50 \%$ [7]. Therefore, CHP has been the key identification of the district heating systems in many countries [8-10]. In Northern China, more than $46 \%$ of the space heating demand is satisfied by CHP (mainly coal-fired CHP units) and the heat supply from CHP will continue to increase rapidly in the future [11,12]. While CHP has the advantage of high-efficiency, the waste heat of exhaust steam is generally inevitable in a cogeneration unit based on a steam turbine (ST), which is attributed to the condensation of the exhaust steam in the condenser and releasing energy to cooling water or air. Normally, the waste heat of exhaust steam may be over $30 \%$ of the total energy consumption in a coal-fueled CHP unit [13]. 
In consequence, recovering the waste energy of exhaust steam is crucial for improving the energy efficiency of cogeneration and conserving the fuel consumed for district heating.

The waste heat recovery of exhaust steam for CHP has been the focus of a great deal of research in the last decade [14-16]. Diminishing the return-water temperature of the primary heating network is an efficient method to utilize the energy of the exhaust steam by heating the low-temperature return-water [17]. A number of authors have reported on setting up absorption heat exchangers at substations, which are driven by high-temperature supply-water of the primary heating network to bring down the return-water temperature to below $20^{\circ} \mathrm{C}$ [18-20]. Another option for waste heat recovery is adopting absorption heat pumps to transfer energy from the exhaust steam to the supply-water of the heating network, which has been theoretically and experimentally investigated by several researchers [21-24]. Tomasz [25] and Ziółkowski [26] discussed the possibility of applying organic Rankine cycle to utilize a large amount of low-grade waste heat from exhaust steam. Besides, promoting the back pressure of the steam turbine and heating the supply-water of the heating network with exhaust steam directly, known as high-back pressure (HBP) heating technology, is also an effective approach to recover the waste heat of exhaust steam, which has been implemented in several cogeneration units of China, such as Yuci, Luhua, Xingneng, etc., creating lots of economic benefits by improving the overall efficiency of CHP $[27,28]$. However, the exhaust steam usually cannot entirely be employed for heating the supply-water of the heating network in a typical coal-fired HBP-CHP unit, which implies that a portion of the exhaust steam energy is still lost to the ambient. Generally, as much as $60-70 \%$ of the exhaust steam may be recycled to heat the supply-water in a HBP heating system under a high heating capacity of the unit, meanwhile, more than $30 \%$ of the exhaust steam with relatively high-quality waste energy is unexploited.

To recover more waste heat of exhaust steam and enhance the performance of the HBP heating design, an improved concept of HBP heating integrated with raw coal pre-drying has been proposed in this study. The feasibility of the new configuration was evaluated on the basis of a $300 \mathrm{MW}$ classical coal-fueled HBP-CHP unit and the thermal performance of the modified cogeneration system was comparatively explored. Energy analysis was applied to reveal the energy-saving mechanism of the proposed concept, and the sensitivity of the optimized HBP-CHP unit was also discussed. The objective of the present paper was to promote the overall efficiency of CHP and reduce GHG emissions.

\section{Reference HBP-CHP Unit}

A representative $300 \mathrm{MW}$ subcritical HBP-CHP unit in Northeast China was deemed as a basic case for comparative investigation, which could be improved by the proposed concept. As depicted in Figure 1, the reference unit includes a pulverized coal-fired boiler and a single-reheating steam turbine. The coal burned by the boiler is lignite with a high concentration of moisture, as given in Table 1 . There are three high-pressure regenerative heaters $(\mathrm{RH})$, one deaerator (DE), and three low-pressure RHs in the heat regenerative system, associated with a direct air-cooling condenser (ACC). The HBP heating design has been exploited in this CHP unit. A part of the exhaust steam is used to heat the supply-water of the primary heating network in the heating condenser $(\mathrm{HC})$. As the back-pressure of the steam turbine remains at $34 \mathrm{kPa}$, the supply-water can be heated up to $70^{\circ} \mathrm{C}$ (the saturation temperature in the $\mathrm{HC}$ is about $72{ }^{\circ} \mathrm{C}$ and the terminal temperature difference is kept above $2{ }^{\circ} \mathrm{C}$ for its high-efficiency operation). Afterward, the warmed supply-water will further obtain energy from the extraction steam in the thermal-system heater (TSH) and be heated up to $80-100{ }^{\circ} \mathrm{C}$. The TSH may not be activated on condition that the supply-water of $70^{\circ} \mathrm{C}$ can meet the heating requirement of the heat users when the weather is not very cold.

Table 2 presents the basic parameters of the case unit under the rated condition during the heating season. This HBP-CHP unit provides the space heating service of 6.67 million square meters for the local residents from October 15th to April 15th of next year. The supply-water is heated from $50{ }^{\circ} \mathrm{C}$ to $94{ }^{\circ} \mathrm{C}$ by the $\mathrm{HC}$ and TSH, and then delivered to the heat consumers through the heating network. Generally, a large portion (about 30-70\%) of the exhaust steam can be recycled to transfer energy to 
the supply-water in the $\mathrm{HC}$, replacing some of the extraction steam that is previously used for heating. Obviously, the more exhaust steam energy is recovered, the more extraction steam can be conserved, and the higher energy efficiency of the HBP-CHP unit will also be promoted. However, more than $30 \%$ of the exhaust steam is usually abandoned in the HBP-CHP unit because the total energy of the exhaust steam is far beyond the requested low-temperature heating capacity.

Table 1. Proximate and ultimate analyses of the raw coal fueled by the reference HBP-CHP unit.

\begin{tabular}{ccc}
\hline Item & & Value \\
\hline & $\mathrm{M}_{\mathrm{ar}}$ & 24.0 \\
Proximate analysis (wt \%) & $\mathrm{M}_{\mathrm{ad}}$ & 10.0 \\
& $\mathrm{~A}_{\mathrm{ar}}$ & 21.3 \\
& $\mathrm{~V}_{\mathrm{ar}}$ & 24.1 \\
& $\mathrm{FC}_{\mathrm{ar}}$ & 30.6 \\
\hline & $\mathrm{C}_{\mathrm{ar}}$ & 39.3 \\
& $\mathrm{H}_{\mathrm{ar}}$ & 2.7 \\
& $\mathrm{O}_{\mathrm{ar}}$ & 11.2 \\
& $\mathrm{~N}_{\mathrm{ar}}$ & 0.6 \\
& $\mathrm{~S}_{\mathrm{ar}}$ & 0.9 \\
\hline Higher heating value (as received basis, $\mathrm{MJ} / \mathrm{kg})$ & 15.7 \\
Lower heating value (as received basis, $\mathrm{MJ} / \mathrm{kg}$ ) & 14.6 \\
\hline
\end{tabular}

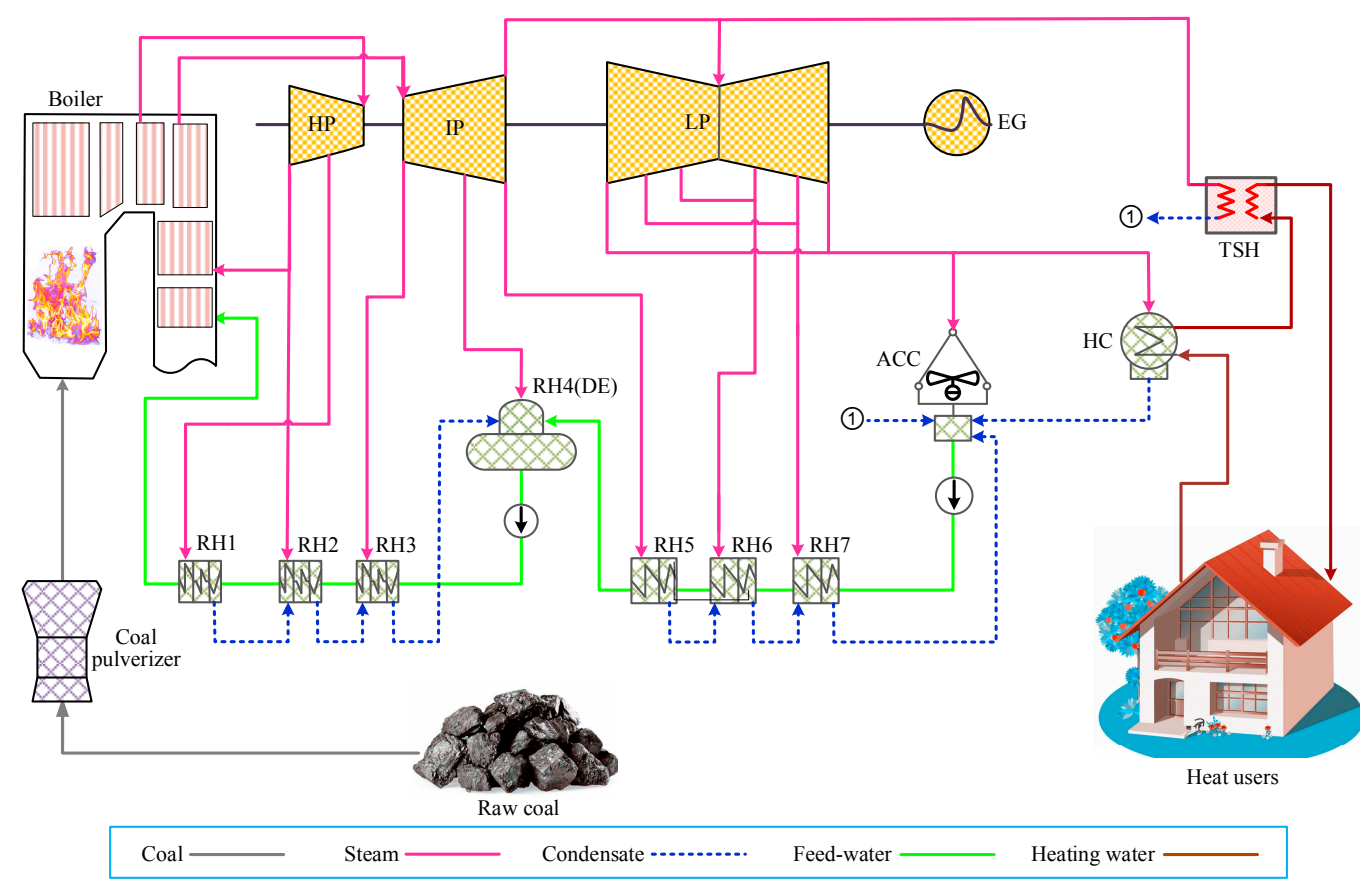

Figure 1. Diagram of the reference coal-fired HBP-CHP unit.

Table 2. Basic parameters of the reference HBP-CHP unit under the rated heating condition.

\begin{tabular}{cccc}
\hline & & Unit & Value \\
\hline \multirow{2}{*}{ Live steam } & Pressure & $\mathrm{MPa}$ & 16.7 \\
& Temperature & ${ }^{\circ} \mathrm{C}$ & 538.0 \\
& Flow rate & $\mathrm{t} / \mathrm{h}$ & 964.2 \\
\hline \multirow{2}{*}{ Reheated steam } & Pressure & $\mathrm{MPa}$ & 3.3 \\
& Temperature & ${ }^{\circ} \mathrm{C}$ & 538.0 \\
& Flow rate & $\mathrm{t} / \mathrm{h}$ & 805.8 \\
\hline
\end{tabular}


Table 2. Cont.

\begin{tabular}{cccc}
\hline \multicolumn{1}{c}{ Item } & Unit & Value \\
\hline \multirow{2}{*}{ Extraction steam for heating } & Pressure & $\mathrm{MPa}$ & 0.37 \\
& Temperature & ${ }^{\circ} \mathrm{C}$ & 297.4 \\
& Flow rate & $\mathrm{t} / \mathrm{h}$ & 216.3 \\
\hline Exhaust steam for heating & Pressure & $\mathrm{kPa}$ & 34.0 \\
& Temperature & ${ }^{\circ} \mathrm{C}$ & 72 \\
\hline Recovery efficiency of the exhaust steam & $\mathrm{t} / \mathrm{h}$ & 216.8 \\
Heating capacity of the unit & $\%$ & 48.8 \\
Generation capacity of the unit & $\mathrm{MW}$ & 300.0 \\
\hline $\begin{array}{c}{ }^{\circ} \\
\text { Supply-water temperature of the primary heating network }\end{array}$ & $\mathrm{MW}$ & 260.0 \\
Return-water temperature of the primary heating network & ${ }^{\circ} \mathrm{C}$ & 94 \\
Area of heat-supply service offered by the unit & $\mathrm{m}^{2}$ & $6.67 \times 10^{6}$ \\
Power generation thermal efficiency of the unit & ${ }^{\circ}$ & 59.3 \\
Power generation standard coal consumption rate of the unit & $\mathrm{g} / \mathrm{kWh}$ & 207.4 \\
\hline
\end{tabular}

\section{Concept Proposal}

Coal pre-drying (mainly for lignite and subbituminous) has been verified to be a practical approach to enhance the performance of the boiler and reduce the energy loss and emissions of exhaust flue gas $[29,30]$. References [31-34] reported that lignite is possible to be dried by low-grade $\left(50-150^{\circ} \mathrm{C}\right)$ heat sources, such as low-temperature air, steam, and flue gas, which can remove most of the surface water involved in the lignite. Hence, the exhaust steam (approximately $34-54 \mathrm{kPa}$ and $72-83^{\circ} \mathrm{C}$, saturated) of a HBP turbine is adequate to offer energy for the desiccation of lignite.

For the sake of further exploiting the exhaust steam of the HBP steam turbine, a new concept of combining the HBP heating and raw coal pre-drying has been developed, as described in Figure 2. The exhaust steam is employed not only for delivering energy to the supply-water through the HC, but also for pre-drying the raw coal by the means of a steam-rotary coal drier (CD). The exhaust steam flows through the $\mathrm{CD}$ and transfers heat to the coal during its condensation, and then the condensate goes back to the regeneration system. Owing to the coal dewatering prior to the coal pulverizer, a portion of the moisture (principally surface water) contained in the lignite is removed and a part of the high-grade energy produced through the coal combustion can be saved, which is originally absorbed by the removed water during its evaporation in the furnace. In other words, the lower heating value (LHV) of the coal would be promoted due to the pre-drying. By diminishing the moisture content of the coal fed into the furnace, the exhaust flue gas energy loss of the boiler can be cut down, and the overall performance of the CHP unit will be enhanced. On account of recovering more exhaust steam for productive purposes, the energy loss of the unit could be reduced, resulting in the efficiency improvement of the unit. The viability and benefits of the modified HBP heating configuration were evaluated on the basis of the reference HBP-CHP unit. 


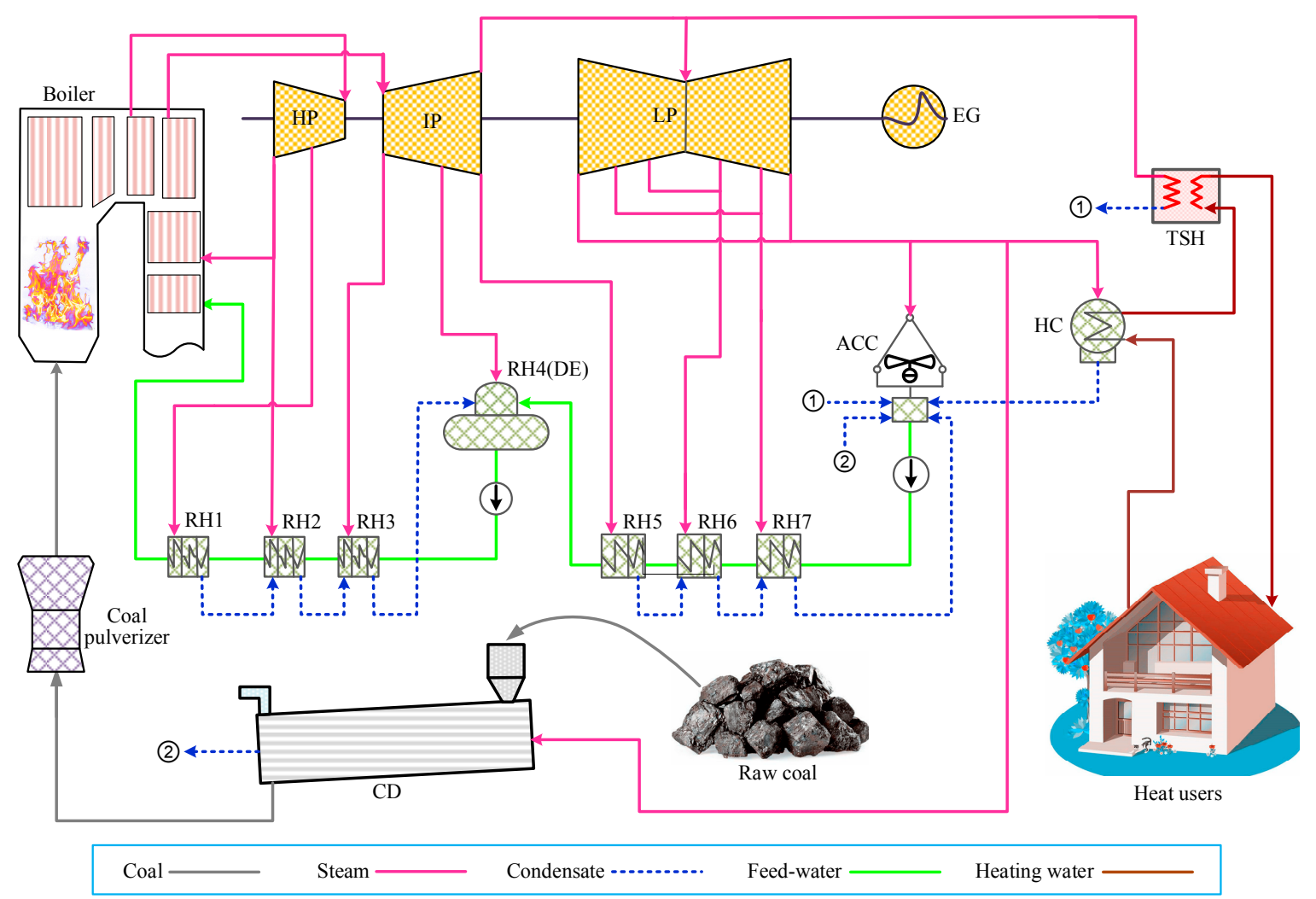

Figure 2. Diagram of the modified HBP heating system integrated with raw coal pre-drying (based on the reference HBP-CHP unit).

\section{Analysis Method}

\subsection{Basic Assumptions}

For comparing the performances of the proposed HBP-CHP unit and original one, the operational parameters of the units were calculated on the basis of the raw coal previous to the drying with the exhaust steam, and the following assumptions were made.

(a) The energy obtained by the live steam and reheat steam in the boiler remained unchanged, and the parameters of the live steam and reheat steam were kept constant;

(b) The exhaust gas temperature of the boiler was fixed;

(c) Besides the energy loss caused by the exhaust flue gas, the other energy loss ratios of the boiler were considered invariable;

(d) The heating capacity and generation capacity of the HBP-CHP unit were maintained unaltered;

(e) The impact of the ambient temperature variation on the unit was neglected.

\subsection{Coal Drying Analysis}

The energy balance of the coal pre-drying process is illustrated in Figure 3. The global heat exchange of the $\mathrm{CD}$ can be described as follows.

$$
\begin{gathered}
Q_{\mathrm{coal}, \text { in }}-Q_{\mathrm{coal}, \text { out }}=Q_{\mathrm{es}-\mathrm{cd}}-Q_{\mathrm{c}-\mathrm{cd}}-Q_{\mathrm{wv}}-Q_{\text {loss }} \\
Q_{\mathrm{coal}, \text { in }}-Q_{\mathrm{coal}, \mathrm{out}}=\frac{\left[h_{\mathrm{coal}, \text { in }}-(1-\alpha) \times h_{\mathrm{coal}, \mathrm{out}}\right] \times m_{\mathrm{coal}}}{3600} \\
Q_{\mathrm{wv}}=\frac{m_{\mathrm{coal}} \times \alpha \times h_{\mathrm{wv}}}{3600}
\end{gathered}
$$




$$
Q_{\mathrm{es}-\mathrm{cd}}-Q_{\mathrm{c}-\mathrm{cd}}=\frac{m_{\mathrm{es}-\mathrm{cd}} \times\left(h_{\mathrm{es}}-h_{\mathrm{c}-\mathrm{cd}}\right)}{3600}
$$

where $Q_{\text {coal,in }}$ and $Q_{\text {coal,out }}$ are the inlet energy and outlet energy of the coal, $\mathrm{MW} ; \alpha$ is the moisture content reduction of the coal after drying, $\mathrm{kg} / \mathrm{kg} ; Q_{\mathrm{es}-\mathrm{cd}}$ and $Q_{\mathrm{c}-\mathrm{cd}}$ are the energy of the inlet exhaust stream and the energy of the outlet condensate, $\mathrm{MW} ; Q_{\mathrm{wv}}$ is the energy of the removed water in the form of vapor, MW; $Q_{\text {loss }}$ is the heat loss due to radiation in the drying process, MW; $h_{\text {coal, in }}$ and $h_{\text {coal,out }}$ are the inlet enthalpy and outlet enthalpy of the coal, $\mathrm{kJ} / \mathrm{kg} ; m_{\text {coal }}$ is the raw coal fueled by the CHP unit per hour, $\mathrm{t} / \mathrm{h} ; m_{\mathrm{es}-\mathrm{cd}}$ is the exhaust steam flow rate for coal pre-drying, $\mathrm{t} / \mathrm{h} ; h_{\mathrm{wv}}$ is the enthalpy of the exhausted water vapor, $\mathrm{kJ} / \mathrm{kg}$; and $h_{\mathrm{es}}$ and $h_{\mathrm{c}-\mathrm{cd}}$ are the enthalpies of the exhaust steam into the $\mathrm{CD}$ and the condensate out of the $\mathrm{CD}, \mathrm{kJ} / \mathrm{kg}$.

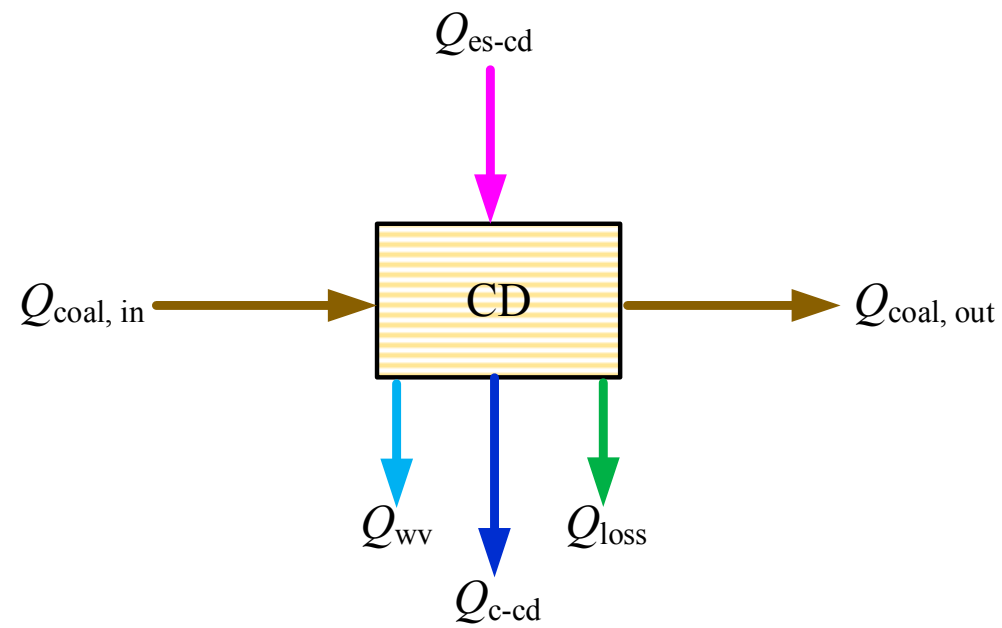

Figure 3. Energy balance of the coal drier during the coal pre-drying process.

Then $m_{\mathrm{es}-\mathrm{cd}}$ can be derived.

$$
m_{\mathrm{es}-\mathrm{cd}}=\frac{\left[h_{\mathrm{coal}, \mathrm{in}}-(1-\alpha) \times h_{\text {coal }, \mathrm{out}}\right] \times m_{\mathrm{coal}}+m_{\mathrm{coal}} \times \alpha \times h_{\mathrm{wv}}+3600 \times Q_{\text {loss }}}{h_{\mathrm{es}}-h_{\mathrm{c}-\mathrm{cd}}}
$$

As the moisture content of the coal declines after drying, the LHV of the coal rises and the new $\mathrm{LHV}\left(q_{\mathrm{LHV}}^{\prime}, \mathrm{kJ} / \mathrm{kg}\right)$ can be expressed as:

$$
q_{\mathrm{LHV}}^{\prime}=\frac{q_{\mathrm{LHV}}+2500 \times \alpha}{1-\alpha}
$$

where $q_{\mathrm{LHV}}$ is the LHV of the raw coal prior to drying, $\mathrm{kJ} / \mathrm{kg}$.

\subsection{Energy Evaluation}

The thermal performance of the HBP-CHP unit was evaluated according to the heat distribution method for CHP [35]. The total heat consumption of the cogeneration unit ( $Q_{\mathrm{th}}, \mathrm{MW}$ ) can be calculated as:

$$
Q_{\mathrm{th}}=\frac{m_{0} \times\left(h_{0}-h_{\mathrm{fw}}\right)+m_{\mathrm{rh}} \times\left(h_{\mathrm{rh}, 0}-h_{\mathrm{rh}, \mathrm{c}}\right)}{3600 \times \eta_{\mathrm{b}-\mathrm{raw}} \times \eta_{\mathrm{p}}}
$$

where $m_{0}$ and $m_{\mathrm{rh}}$ are the flow rates of the live steam and the reheat steam, $\mathrm{t} / \mathrm{h} ; h_{0}$ and $h_{\mathrm{fw}}$ are the enthalpies of the live steam and the feed-water, $\mathrm{kJ} / \mathrm{kg} ; h_{\mathrm{rh}, 0}$ and $h_{\mathrm{rh}, \mathrm{c}}$ are the enthalpies of the reheated steam and the cold reheat steam before reheating, $\mathrm{kJ} / \mathrm{kg} ; \eta_{\mathrm{b}-\text { raw }}$ is the boiler efficiency on the basis of the raw coal before drying, $\%$; and $\eta_{\mathrm{p}}$ is the pipe efficiency $\%$, which was set as $99.0 \%$ in the calculation. 
In order to examine the overall efficiency of the cogeneration system including the raw coal pre-dying process, the boiler efficiency was considered based on the raw coal, and $\eta_{\mathrm{b}-\text { raw }}$ is defined as:

$$
\eta_{\mathrm{b}-\text { raw }}=\frac{m_{0} \times\left(h_{0}-h_{\mathrm{fw}}\right)+m_{\mathrm{rh}} \times\left(h_{\mathrm{rh}, 0}-h_{\mathrm{rh}, \mathrm{c}}\right)}{m_{\mathrm{coal}} \times q_{\mathrm{LHV}} \times \eta_{\mathrm{p}}}
$$

The heat consumption for heating of the HBP-CHP unit $\left(Q_{h}, M W\right)$ includes the heat absorbed by the supply-water in the HC $\left(Q_{\mathrm{h} 1}, \mathrm{MW}\right)$ and the heat transferred to the supply-water in the TSH $\left(Q_{\mathrm{h} 2}, \mathrm{MW}\right)$, formulated as:

$$
\begin{gathered}
Q_{\mathrm{h}}=Q_{\mathrm{h} 1}+Q_{\mathrm{h} 2} \\
Q_{\mathrm{h} 1}=\frac{m_{\mathrm{es}-\mathrm{h}} \times\left(h_{\mathrm{es}}-h_{\mathrm{es}}^{\prime}\right)}{3600 \times \eta_{\mathrm{b}-\mathrm{raw}} \times \eta_{\mathrm{p}}} \\
Q_{\mathrm{h} 2}=\frac{m_{\mathrm{ex}} \times\left(h_{\mathrm{ex}}-h_{\mathrm{ex}}^{\prime}\right)}{3600 \times \eta_{\mathrm{b}-\mathrm{raw}} \times \eta_{\mathrm{p}}}
\end{gathered}
$$

where $m_{\mathrm{es}-\mathrm{h}}$ and $m_{\mathrm{ex}}$ are the flow rates of the exhaust steam into the HC and the extraction steam from the intermediate-pressure turbine for heating, $\mathrm{t} / \mathrm{h} ; h_{\mathrm{es}}$ and $h_{\mathrm{es}}^{\prime}$ are the enthalpies of the exhaust steam and the condensate in the $\mathrm{HC}, \mathrm{kJ} / \mathrm{kg}$. and $h_{\mathrm{ex}}$ and $h_{\mathrm{ex}}^{\prime}$ are the enthalpies of the extraction steam for heating and the condensate in the TSH, $\mathrm{kJ} / \mathrm{kg}$.

The heat consumption for power generation of the HBP-CHP unit $\left(Q_{e}, M W\right)$ can be calculated as:

$$
Q_{\mathrm{e}}=Q_{\mathrm{th}}-Q_{\mathrm{h}}
$$

The power generation thermal efficiency of the CHP unit $\left(\eta_{\mathrm{e}}, \%\right)$ is expressed as:

$$
\eta_{\mathrm{e}}=\frac{P_{\mathrm{e}}}{Q_{\mathrm{e}}} \times 100 \%
$$

where $P_{\mathrm{e}}$ is the generation capacity of the unit, MW.

The power generation standard coal consumption rate of the CHP unit $\left(b_{\mathrm{e}}^{\mathrm{s}}, \mathrm{g} / \mathrm{kWh}\right)$ is formulated as:

$$
b_{\mathrm{e}}^{\mathrm{s}}=\frac{123}{\eta_{\mathrm{e}}}
$$

The exhaust steam condenses and releases heat to air in the air-cooling condenser, resulting in the energy loss of the exhaust steam ( $\left.Q_{\mathrm{es}-\text { loss }}, \mathrm{MW}\right)$.

$$
Q_{\mathrm{es}-\mathrm{loss}}=\frac{\left(m_{\mathrm{es}}-m_{\mathrm{es}-\mathrm{h}}-m_{\mathrm{es}-\mathrm{cd}}\right) \times\left(h_{\mathrm{es}}-h_{\mathrm{es}}^{\prime}\right)}{3600}
$$

where $m_{\mathrm{es}}$ is the total flow rate of the exhaust steam from the low-pressure turbine, $\mathrm{t} / \mathrm{h}$.

To assess the waste heat utilization of the HBP heating system, the recovery efficiency of the exhaust steam $\left(\eta_{\mathrm{re}}, \%\right)$ was put forward and expressed as:

$$
\eta_{\mathrm{re}}=\frac{m_{\mathrm{es}-\mathrm{h}}+m_{\mathrm{es}-\mathrm{cd}}}{m_{\mathrm{es}}} \times 100 \%
$$

\section{Results and Discussion}

\subsection{Coal after Pre-Drying}

As the free water in the lignite can be easily expelled using the steam-rotary dryer [36-38], the moisture content of the raw coal is assumed to decline from $24.0 \%$ to $10.0 \%$ due to the pre-drying. The compositions of the raw coal and dried coal are presented in Table 3. Since the raw coal is updated by dewatering and its contained moisture is cut down, the LHV of the coal increases from $14.6 \mathrm{MJ} / \mathrm{kg}$ 
to $17.7 \mathrm{MJ} / \mathrm{kg}$, meanwhile, much less water will be carried into the boiler furnace with the coal, while the total raw coal consumption remains constant.

Table 3. Proximate and ultimate analyzes of the raw coal and dried coal.

\begin{tabular}{cccc}
\hline Item & & Raw Coal & Dried Coal \\
\hline & $\mathrm{M}_{\mathrm{ar}}$ & 24.0 & 10.0 \\
& $\mathrm{M}_{\mathrm{ad}}$ & 10.0 & 10.0 \\
Proximate analysis (wt. \%) & $\mathrm{A}_{\mathrm{ar}}$ & 21.3 & 25.2 \\
& $\mathrm{~V}_{\mathrm{ar}}$ & 24.1 & 28.5 \\
& $\mathrm{FC}_{\mathrm{ar}}$ & 30.6 & 36.3 \\
\hline & $\mathrm{C}_{\mathrm{ar}}$ & 39.3 & 46.5 \\
& $\mathrm{H}_{\mathrm{ar}}$ & 2.7 & 3.2 \\
Ultimate analysis (wt. \%) & $\mathrm{O}_{\mathrm{ar}}$ & 11.2 & 13.3 \\
& $\mathrm{~N}_{\mathrm{ar}}$ & 0.6 & 0.7 \\
& $\mathrm{~S}_{\mathrm{ar}}$ & 0.9 & 1.1 \\
\hline Lower heating value (as received basis, $\mathrm{MJ} / \mathrm{kg})$ & 14.6 & 17.7 \\
\hline
\end{tabular}

\subsection{Overall Performance}

The thermal performances of the regular HBP-CHP unit and optimized one were contrastively examined under the same condition (rated heating condition), namely, the parameters of the live steam and reheat steam; the heating and generation capacities and so on were identical for the two units, and the results are given in Table 4. By dewatering the raw coal with the exhaust steam in the proposed design, the recovery efficiency of the exhaust steam rises from $48.8 \%$ to $56.7 \%$, in the meantime, the energy loss of the exhaust steam in the ACC drops by $22.0 \mathrm{MW}$. On account of drying the raw coal before its combustion in the furnace, the water content of the coal fed into the boiler is lessened, which results in that the energy loss of the exhaust flue gas declines dramatically, contributing to promoting the boiler efficiency from $92.7 \%$ to $95.4 \%$. As a consequence, the power generation thermal efficiency of the CHP unit is improved from $59.3 \%$ to $61.0 \%$ by the new concept, leading to a reduction of $5.8 \mathrm{~g} / \mathrm{kWh}$ in the power generation standard coal consumption rate of the unit. In general, the total raw coal consumption of the unit falls by $5.4 \mathrm{t} / \mathrm{h}$ through the raw coal dehydration using exhaust steam and the unit cost of power generation drops by $0.66 \mathrm{USD} / \mathrm{MWh}$.

According to the actual operating data of the reference HBP-CHP unit during the heating season from October 2017 to April 2018 (Table 5), the economic benefit brought by the proposed design in one whole heating season was estimated. Based on the average parameters in different months, the conserved fuel attributed to the suggested retrofitting that could be calculated. The results indicate that meeting the same heat and electricity demands in the entire heating season, the modified HBP-CHP unit burns 9.80 thousand tons less standard coal than the conventional one, which creates the economic benefit of 1.11 million dollars. 
Table 4. Overall performances of the original HBP-CHP unit and the proposed HBP-CHP unit.

\begin{tabular}{|c|c|c|c|}
\hline Item & Original Unit & Proposed Unit & Variation (Absolute Value) \\
\hline Live steam flow rate $(\mathrm{t} / \mathrm{h})$ & 964.2 & 964.2 & - \\
\hline Reheat steam flow rate $(\mathrm{t} / \mathrm{h})$ & 805.8 & 805.8 & - \\
\hline Flow rate of the extraction steam for heating $(\mathrm{t} / \mathrm{h})$ & 216.3 & 216.3 & - \\
\hline Flow rate of the exhaust steam for heating $(\mathrm{t} / \mathrm{h})$ & 216.8 & 216.8 & - \\
\hline Flow rate of the exhaust steam into the $A C C(\mathrm{t} / \mathrm{h})$ & 227.5 & 192.6 & -34.9 \\
\hline Heating capacity of the unit (MW) & 300.0 & 300.0 & - \\
\hline Generation capacity of the unit (MW) & 260.0 & 260.0 & - \\
\hline Energy loss of the exhaust steam in the ACC (MW) & 136.1 & 114.1 & -22.0 \\
\hline Recovery efficiency of the exhaust steam (\%) & 48.8 & 56.7 & +7.9 \\
\hline Energy loss of the exhaust flue gas from the boiler (MW) & 108.3 & 85.2 & -23.1 \\
\hline Boiler efficiency based on the raw coal (\%) & 92.7 & 95.4 & +2.7 \\
\hline $\begin{array}{l}\text { Power generation thermal efficiency of the unit based on } \\
\text { the raw coal (\%) }\end{array}$ & 59.3 & 61.0 & +1.7 \\
\hline $\begin{array}{l}\text { Power generation standard coal consumption rate of the } \\
\text { unit based on the raw coal }(\mathrm{g} / \mathrm{kWh})\end{array}$ & 207.4 & 201.6 & -5.8 \\
\hline Total raw coal fueled by the unit per hour $(\mathrm{t} / \mathrm{h})$ & 189.0 & 183.6 & -5.4 \\
\hline Standard coal price (USD/t) [39] & 113 & 113 & - \\
\hline Cost of power generation (USD/MWh) & 23.44 & 22.78 & -0.66 \\
\hline
\end{tabular}

Note: The variation value is equal to the value of the proposed unit minus that of the original unit.

Table 5. Average operating parameters of the reference HBP-CHP unit in different months of the heating season from 2017 to 2018.

\begin{tabular}{ccccccccc}
\hline \multirow{2}{*}{ Item } & \multicolumn{9}{c}{$\mathbf{2 0 1 7}$} & $\mathbf{2 0 1 8}$ \\
\cline { 2 - 8 } & October & November & December & January & February & March & April \\
\hline Heat-service days & 15 & 30 & 31 & 31 & 28 & 31 & 15 \\
Generation capacity of the unit (MW) & 172 & 209 & 247 & 264 & 258 & 193 & 163 \\
Heating capacity of the unit $(\mathrm{MW})$ & 164 & 247 & 299 & 317 & 309 & 231 & 149 \\
Supply-water temperature $\left({ }^{\circ} \mathrm{C}\right)$ & 44 & 47 & 49 & 50 & 50 & 46 & 43 \\
Return-water temperature $\left({ }^{\circ} \mathrm{C}\right)$ & 81 & 87 & 92 & 95 & 94 & 85 & 80 \\
\hline
\end{tabular}

\subsection{Energy Flows}

To explore the root cause of the energy-saving due to the proposed concept and to discover the details of the energy migration caused by the raw coal pre-drying, the primary energy flows that took place in the original HBP-CHP unit and modified one were outlined, as depicted in Figure 4. The energy contained in the coal was calculated based on its higher heating value (HHV), and the theoretical energy flows of the dry flue gas and the water vapor were considered separately for detecting the energy variation of the coal due to its dehydration. In the optimized unit, while a portion of the exhaust steam is used for dewatering the raw coal, the energy of 22.0 MW is transferred from the exhaust steam to the raw coal in the steam-rotary $C D$, and some water vapor is separated and discharged. As a consequence, the energy loss of the exhaust steam drops by $22.0 \mathrm{MW}(2.74 \%)$ and the exhaust steam recovery efficiency increases by $7.9 \%$ (absolute value), as compared to the conventional design. In theory, the energy of the raw coal (823.6 MW, 100\%) can convert into the energy of the dry flue gas (632.2 MW, 76.75\%) and the energy of the water vapor (191.4 MW, 23.25\%) during the combustion in the boiler of the original unit, resulting in a large energy waste of the exhaust flue gas (108.3 MW, 13.15\%), including 69.9 MW (8.48\%) energy carried by the water vapor. However, the moisture content of the raw coal is significantly reduced by pre-drying in the new cogeneration system, hence less energy is taken along with the water vapor after the coal burning. In the modified unit, the energy of the dried coal (800.2 MW, 100\%) turns into the energy of the dry flue gas (661.7 MW, $82.69 \%$ ) and the energy of the water vapor (138.5 MW, $17.31 \%)$ after combustion, and the energy share of the water vapor diminishes from $23.25 \%$ to $17.31 \%$. Furthermore, the energy loss of the exhausted water vapor falls by $2.46 \%$ (absolute value) and the total energy loss of the exhaust flue gas declines by $2.51 \%$ (absolute value). As the energy loss of the exhaust flue gas is reduced significantly, the boiler 
efficiency (based on the raw coal) is enhanced and less raw coal is needed to produce the same live steam and reheated steam in the proposed HBP-CHP unit.

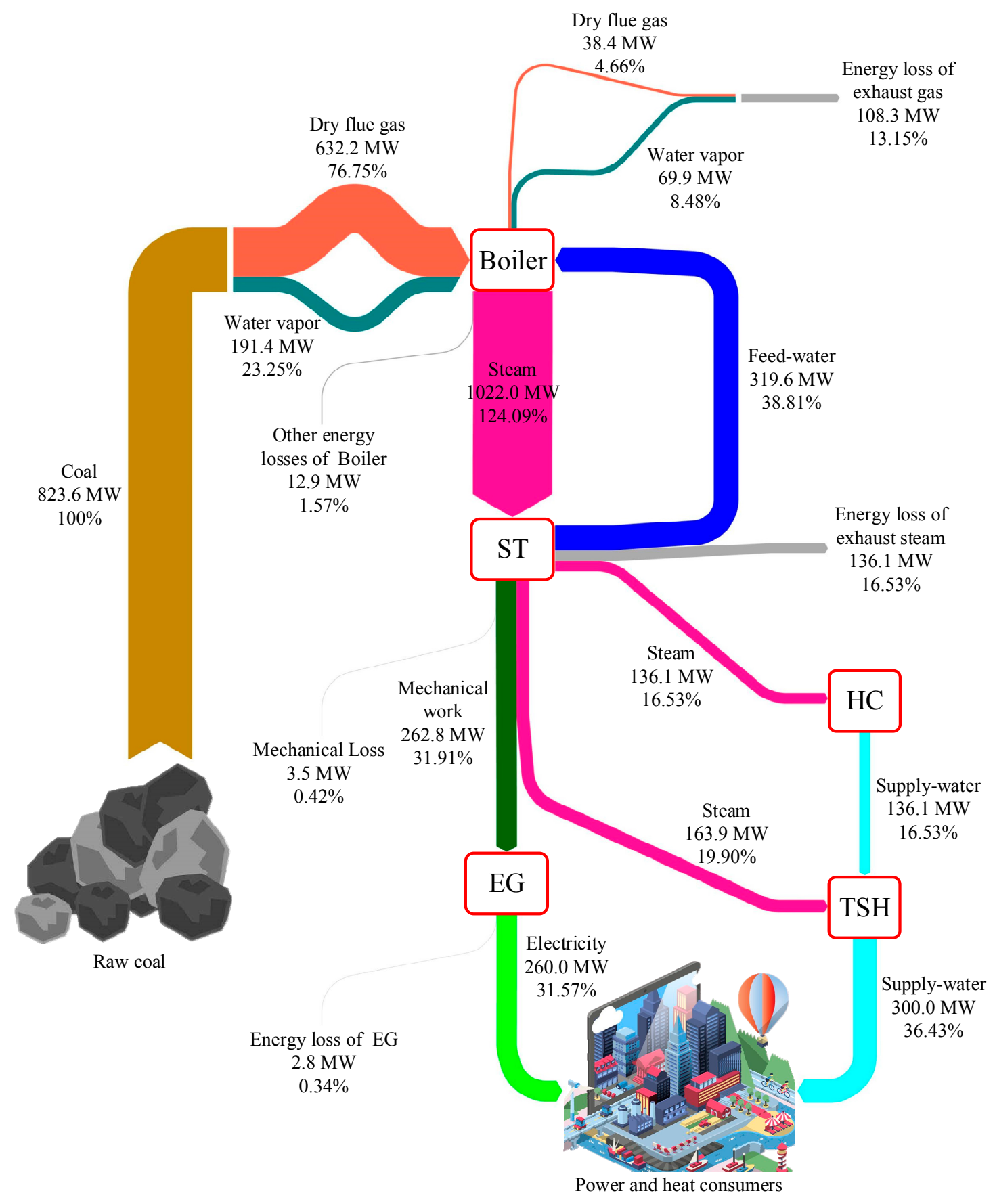

(a)

Figure 4. Cont. 


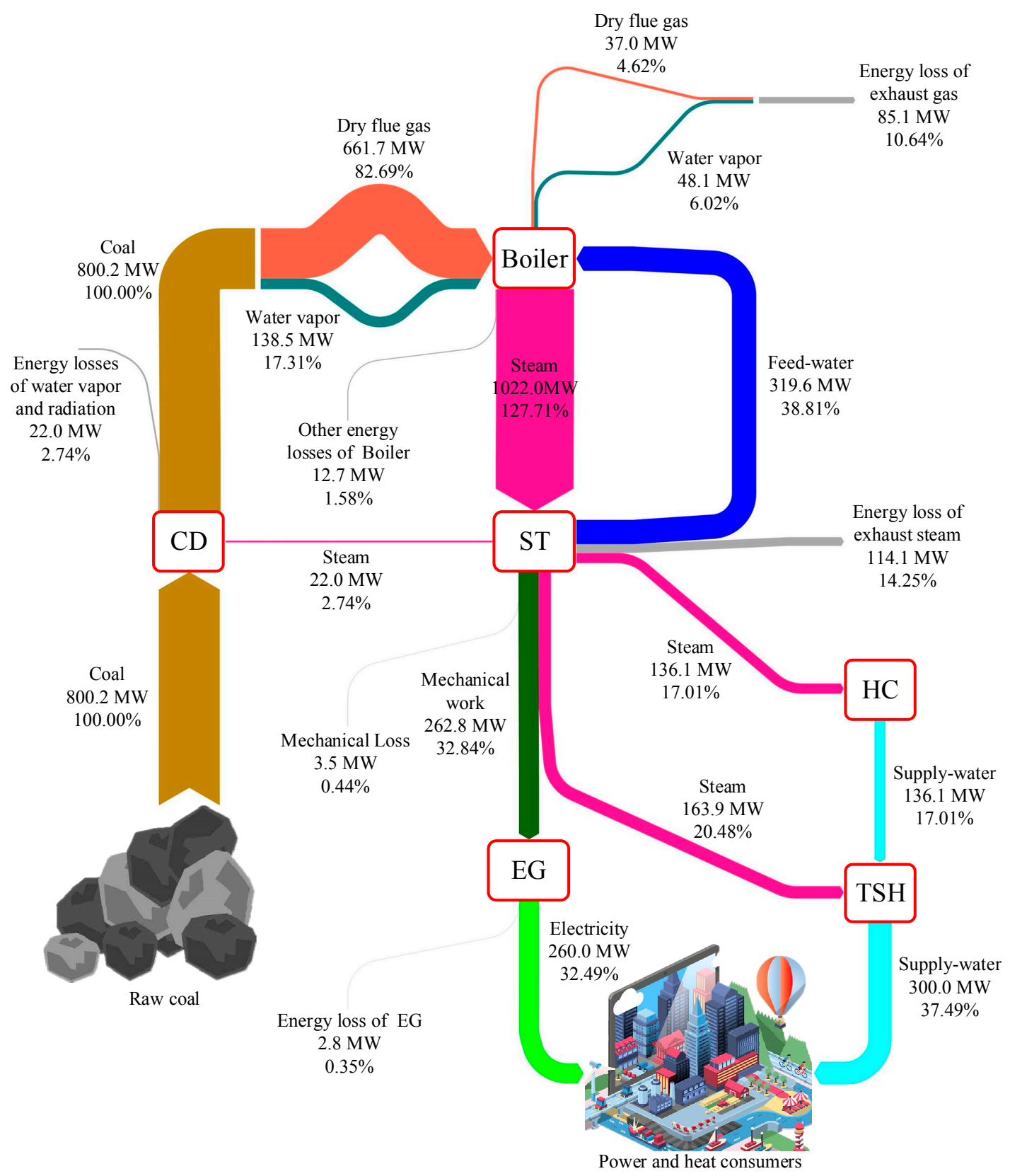

(b)

Figure 4. Diagram of the primary energy flows in the original HBP-CHP unit and proposed HBP-CHP unit: (a) Original unit; and (b) Proposed unit.

\subsection{Sensitivity}

During the pre-drying of the raw coal, a part of the moisture contained in the raw coal is expelled in the form of vapor and the water vapor is discharged out of the CD. The relationship between the water content of the dried coal and the energy-saving benefit of the proposed design was investigated based on the raw coal prior to dewatering, as illustrated in Figure 5. As more water is evicted from the raw coal, more energy needs to be provided by the exhaust steam, and the recovery efficiency of the exhaust steam rises. Besides, the energy taken along with the water vapor after the coal combustion in the boiler furnace will fall with the decrease of the water content in the dried coal, conducive to lessening the energy loss of the flue gas drained from the boiler, which enhances the boiler performance and cuts down the total raw coal consumption of the cogeneration unit. When the moisture content of 
the coal drops from $24 \%$ to $10 \%$ due to the pre-drying, the total raw coal consumption of the unit is reduced by $5.4 \mathrm{t} / \mathrm{h}(2.86 \%)$.

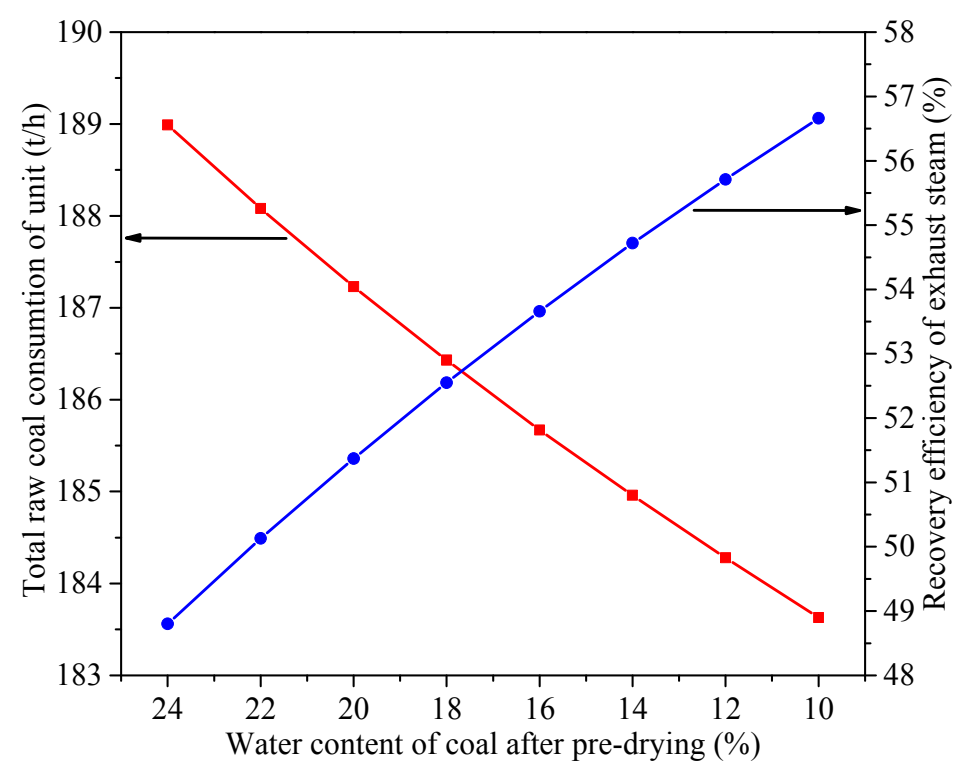

Figure 5. Impact of the moisture content in the dried coal on the performance of the proposed design.

Figure 6 shows the effect of the unit heating capacity on the performance of the modified configuration. When the unit heating capacity gets larger, the total raw coal consumptions of the original HBP-CHP unit and proposed one are raised and the coal consumption reduction caused by the new concept also becomes a little bigger, but the variation is not distinct. As the unit heating capacity ranges from $180 \mathrm{MW}$ to $380 \mathrm{MW}$, the coal consumption reduction only rises from $5.14 \mathrm{~g} / \mathrm{kWh}$ to $5.49 \mathrm{~g} / \mathrm{kWh}$, though the recovery efficiency promotion owing to the optimized design increases from $6.65 \%$ to $8.87 \%$ (absolute value). It is evident that the energy-saving effect of the modified HBP heating system is relatively constant while the unit heating capacity changes, which implies that steady economic returns can be brought through the proposed retrofitting during the heating season.

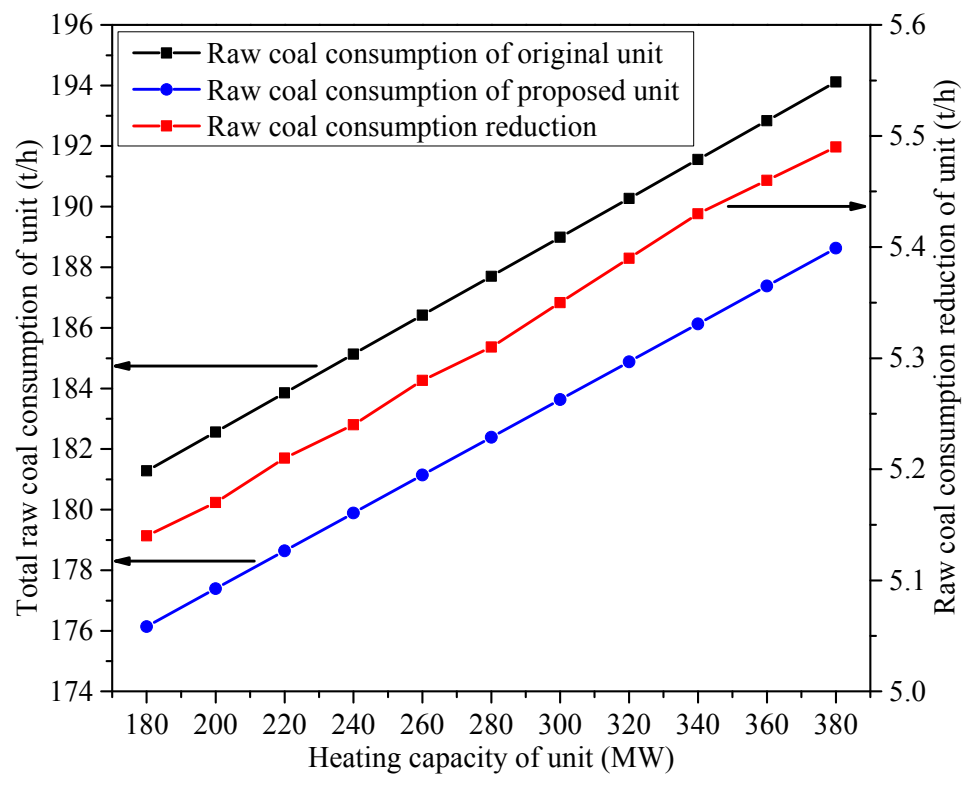

(a)

Figure 6. Cont. 


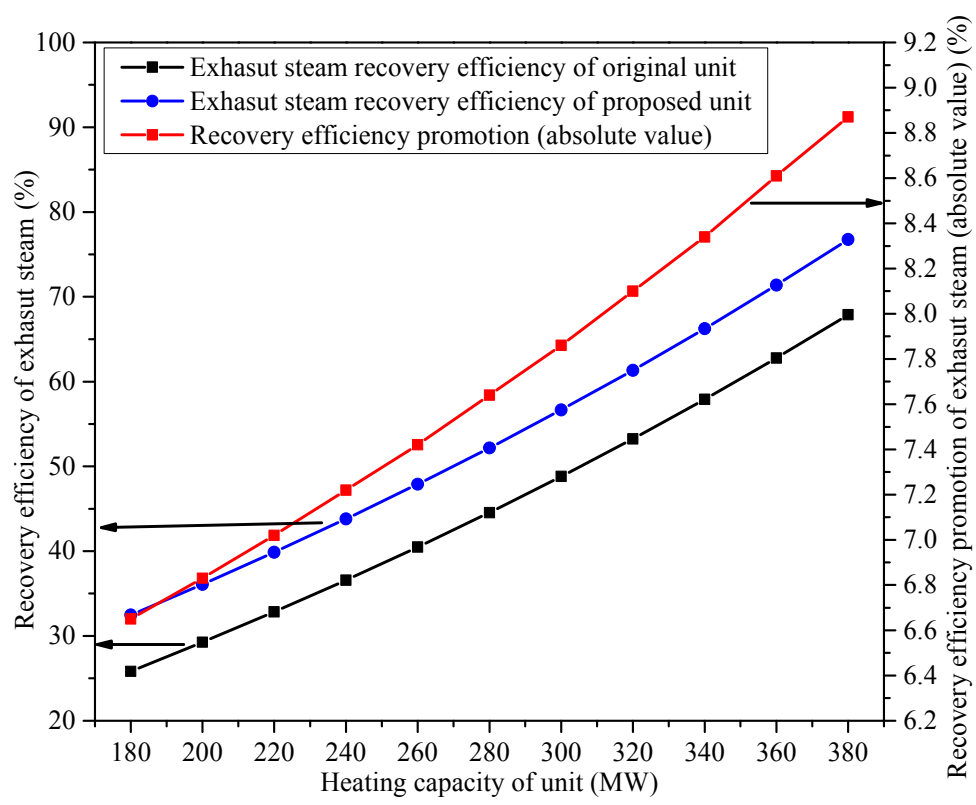

(b)

Figure 6. Impact of the unit heating capacity on the performance of the proposed design: (a) Total raw coal consumption of unit; and (b) recovery efficiency of the exhaust steam.

\section{Conclusions}

A hybrid system of HBP heating and raw coal pre-drying for $\mathrm{CHP}$ has been proposed and its feasibility was investigated with thermodynamic and economic analyses based on a $300 \mathrm{MW}$ coal-fired HBP-CHP unit. The results indicate that the power generation thermal efficiency of the cogeneration unit is raised from $59.3 \%$ to $61.0 \%$, caused by the new concept, resulting in the power generation standard coal consumption rate reduction of $5.8 \mathrm{~g} / \mathrm{kWh}$. Consequently, 9.80 thousand tons of standard coal can be conserved in an entire heating season and the economic benefit of 1.11 million dollars can be created. Through drying the raw coal with the exhaust steam, the energy loss of the exhaust steam can further be diminished and the recovery efficiency of the exhaust steam rises from $48.8 \%$ to $56.7 \%$, conducing to enhancing the overall efficiency of the unit. As the raw coal is pre-dried prior to the boiler furnace, nearly all the free water contained in the raw coal can be removed and the LHV of the coal increases by $17.6 \%$. Moreover, the energy loss of the exhaust flue gas of the boiler drops remarkably and the boiler efficiency is promoted from $92.7 \%$ to $95.4 \%$. While the moisture content of the dried coal declines, the energy-saving gain of the proposed configuration will significantly rise. When the unit heating capacity goes up, the modified design will recover more energy from the exhaust steam and contributes to conserving a little more fuel. Since lots of energy-saving and economic benefits can be expected due to the proposed concept, the new design is suggested to be widely applied in the HBP-CHP units burning coal with a high moisture content.

Author Contributions: Conceptualization, H.C. and G.X.; Data curation, Q.C.; Formal analysis, H.C. and Z.Q.; Funding acquisition, G.X. and Y.Y.; Investigation, H.C., Z.Q. and Y.W.; Methodology, Z.Q. and Y.W.; Software, Z.Q. and Q.C.; Supervision, G.X. and Y.Y.; Validation, Q.C. and Y.W.; Writing-original draft, H.C. and Q.C.; Writing-review \& editing, G.X.

Funding: This work was supported by the National Nature Science Fund of China (No. 51476053), the National Key R\&D Program of China (No. 2017YFB0602104), and the Fundamental Research Funds for the Central Universities (No. 2015ZZD10).

Conflicts of Interest: The authors declare no conflict of interest. 


\section{Nomenclature}

\begin{tabular}{|c|c|c|c|}
\hline \multicolumn{2}{|c|}{ Abbreviations } & \multicolumn{2}{|c|}{ Subscripts and superscript } \\
\hline $\mathrm{ACC}$ & air-cooling condenser & 0 & initial \\
\hline $\mathrm{CD}$ & coal dryer & ad & air dry basis \\
\hline DE & deaerator & ar & as received basis \\
\hline EG & electricity generator & $\mathrm{b}$ & boiler \\
\hline $\mathrm{HC}$ & heating condenser & C & condensate/cold \\
\hline $\mathrm{HHV}$ & higher heating value & $\mathrm{cd}$ & coal drying \\
\hline $\mathrm{HP}$ & high-pressure turbine & $\mathrm{e}$ & electricity \\
\hline IP & intermediate-pressure turbine & es & exhaust steam \\
\hline LHV & lower heating value & ex & extraction steam \\
\hline LP & low-pressure turbine & fw & feed-water \\
\hline $\mathrm{RH}$ & regenerative heater & $\mathrm{h}$ & heating \\
\hline ST & steam turbine & re & recovery \\
\hline TSH & thermal-system heater & rh & reheat \\
\hline Symbols & & $\mathrm{s}$ & standard coal \\
\hline$\alpha$ & removed water content $(\mathrm{kg} / \mathrm{kg})$ & th & total heat \\
\hline$\eta$ & efficiency (\%) & $\mathrm{p}$ & pipe \\
\hline$P$ & generation capacity (MW) & wV & water vapor \\
\hline$Q$ & heat (MW) & & \\
\hline$h$ & specific enthalpy $(\mathrm{kJ} / \mathrm{kg})$ & & \\
\hline$m$ & mass flow rate $(\mathrm{t} / \mathrm{h})$ & & \\
\hline$q$ & specific heat $(\mathrm{kJ} / \mathrm{kg})$ & & \\
\hline
\end{tabular}

\section{References}

1. U.S. National Academy of Sciences and Royal Society. Climate Change: Evidence E Causes; National Academies Press: Washington, DC, USA, 2014.

2. Pié, L.; Fabregat-Aibar, L.; Saez, M. The influence of imports and exports on the evolution of greenhouse gas emissions: The case for the European Union. Energies 2018, 11, 1644. [CrossRef]

3. Rezaie, B.; Rosen, M.A. District heating and cooling: Review of technology and potential enhancements. Appl. Energy 2012, 93, 2-10. [CrossRef]

4. Liu, M.; Shi, Y.; Fang, F. Combined cooling, heating and power systems: A survey. Renew. Sustain. Energy Rev. 2014, 35, 1-22. [CrossRef]

5. Amber, K.; Day, T.; Ratyal, N.; Kiani, A.; Ahmad, R. Techno, economic and environmental assessment of a combined heat and power (CHP) system-A case study for a university campus. Energies 2018, 11, 1133. [CrossRef]

6. Helin, K.; Zakeri, B.; Syri, S. Is district heating combined heat and power at risk in the Nordic area?-An electricity market perspective. Energies 2018, 11, 1256. [CrossRef]

7. Gustafsson, J.; Delsing, J.; van Deventer, J. Improved district heating substation efficiency with a new control strategy. Appl. Energy 2010, 87, 1996-2004. [CrossRef]

8. Werner, S. International review of district heating and cooling. Energy 2017, 137, 617-631. [CrossRef]

9. Lake, A.; Rezaie, B.; Beyerlein, S. Review of district heating and cooling systems for a sustainable future. Renew. Sustain. Energy Rev. 2017, 67, 417-425. [CrossRef]

10. Madsen, K.; Bentsen, N. Carbon debt payback time for a biomass fired CHP plant-A case study from Northern Europe. Energies 2018, 11, 807. [CrossRef]

11. Xu, X.; You, S.; Zheng, X.; Li, H. A survey of district heating systems in the heating regions of northern China. Energy 2014, 77, 909-925. [CrossRef]

12. Gong, M.; Werner, S. An assessment of district heating research in China. Renew. Energy 2015, 84, 97-105. [CrossRef]

13. Li, Y.; Wang, W.; Ma, Y.; Li, W. Study of new cascade heating system with multi-heat sources based on exhausted steam waste heat utilization in power plant. Appl. Therm. Eng. 2018, 136, 475-483. [CrossRef] 
14. Li, W.; Zhao, J.; Fu, L.; Yuan, W.; Zheng, Z.; Li, Y. Energy efficiency analysis of condensed waste heat recovery ways in cogeneration plant. Energy Convers. Manag. 2015, 101, 616-625. [CrossRef]

15. Li, Y.; Chang, S.; Fu, L.; Zhang, S. A technology review on recovering waste heat from the condensers of large turbine units in China. Renew. Sustain. Energy Rev. 2016, 58, 287-296. [CrossRef]

16. Chen, H.; Xu, J.; Xiao, Y.; Qi, Z.; Xu, G.; Yang, Y. An improved heating system with waste pressure utilization in a combined heat and power unit. Energies 2018, 11, 1515. [CrossRef]

17. Gadd, H.; Werner, S. Achieving low return temperatures from district heating substations. Appl. Energy 2014, 136, 59-67. [CrossRef]

18. Li, Y.; Fu, L.; Zhang, S.; Jiang, Y.; Zhao, X. A new type of district heating method with co-generation based on absorption heat exchange (co-ah cycle). Energy Convers. Manag. 2011, 52, 1200-1207. [CrossRef]

19. Sun, F.; Cheng, L.; Fu, L.; Gao, J. New low temperature industrial waste heat district heating system based on natural gas fired boilers with absorption heat exchangers. Appl. Therm. Eng. 2017, 125, 1437-1445. [CrossRef]

20. Sun, J.; Ge, Z.; Fu, L. Investigation on operation strategy of absorption heat exchanger for district heating system. Energy Build. 2017, 156, 51-57. [CrossRef]

21. Ommen, T.; Markussen, W.B.; Elmegaard, B. Heat pumps in combined heat and power systems. Energy 2014, 76, 989-1000. [CrossRef]

22. Sun, J.; Fu, L.; Sun, F.; Zhang, S. Experimental study on a project with CHP system basing on absorption cycles. Appl. Therm. Eng. 2014, 73, 732-738. [CrossRef]

23. Cho, H.; Sarwar, R.; Mago, P.J.; Luck, R. Design and feasibility study of combined heat and power systems integrated with heat pump. Appl. Therm. Eng. 2016, 93, 155-165. [CrossRef]

24. Zhang, H.S.; Zhao, H.B.; Li, Z.L. Performance analysis of the coal-fired power plant with combined heat and power (CHP) based on absorption heat pumps. J. Energy Inst. 2016, 89, 70-80. [CrossRef]

25. Tomasz, K.; Pawel, Z.; Janusz, B. Exergy analysis of the Szewalski cycle with a waste heat recovery system. Arch. Thermodyn. 2015, 36, 25-48.

26. Ziółkowski, P.; Kowalczyk, T.; Kornet, S.; Badur, J. On low-grade waste heat utilization from a supercritical steam power plant using an ORC-bottoming cycle coupled with two sources of heat. Energy Convers. Manag. 2017, 146, 158-173. [CrossRef]

27. Zhao, S.; Ge, Z.; He, J.; Wang, C.; Yang, Y.; Li, P. A novel mechanism for exhaust steam waste heat recovery in combined heat and power unit. Appl. Energy 2017, 204, 596-606. [CrossRef]

28. Ge, Z.; Zhang, F.; Sun, S.; He, J.; Du, X. Energy Analysis of cascade heating with high back-pressure large-scale steam turbine. Energies 2018, 11, 119. [CrossRef]

29. Jangam, S.V.; Karthikeyan, M.; Mujumdar, A.S. A critical assessment of industrial coal drying technologies: Role of energy, emissions, risk and sustainability. Dry. Technol. 2011, 29, 395-407. [CrossRef]

30. Man, C.; Zhu, X.; Gao, X.; Che, D. Combustion and pollutant emission characteristics of lignite dried by low temperature air. Dry. Technol. 2015, 33, 616-631. [CrossRef]

31. Bullinger, C.; Ness, M.; Sarunac, N.; Levy, E.K. Coal drying improves performance and reduces emissions. In Proceedings of the 27th International Technical Conference on Coal Utilization \& Fuel Systems, Clearwater, FL, USA, 4-7 March 2002.

32. Xu, C.; Xu, G.; Yang, Y.; Zhao, S.; Zhang, K.; Zhang, D. An improved configuration of low-temperature pre-drying using waste heat integrated in an air-cooled lignite fired power plant. Appl. Therm. Eng. 2015, 90, 312-321. [CrossRef]

33. Liu, M.; Wu, D.; Xiao, F.; Yan, J. A novel lignite-fired power plant integrated with a vacuum dryer: System design and thermodynamic analysis. Energy 2015, 82, 968-975. [CrossRef]

34. Xu, C.; Xu, G.; Zhu, M.; Dong, W.; Zhang, Y.; Yang, Y.; Zhang, D. Thermodynamic analysis and economic evaluation of a $1000 \mathrm{MW}$ bituminous coal fired power plant incorporating low-temperature pre-drying (LTPD). Appl. Therm. Eng. 2016, 96, 613-622. [CrossRef]

35. Zheng, T. Thermal Energy \& Power, 2nd ed.; China Electric Power Press: Beijing, China, 2008. (In Chinese)

36. Xu, G.; Dong, W.; Xu, C.; Liu, Q.; Yang, Y. An integrated lignite pre-drying system using steam bleeds and exhaust flue gas in a 600MW power plant. Appl. Therm. Eng. 2016, 107, 1145-1157. [CrossRef]

37. Xu, C.; Bai, P.; Xin, T.; Hu, Y.; Xu, G.; Yang, Y. A novel solar energy integrated low-rank coal fired power generation using coal pre-drying and an absorption heat pump. Appl. Energy 2017, 200, 170-179. [CrossRef] 
38. Xu, C.; Sun, Y.; Xin, T.; Xu, G.; Zhu, M.; Yang, Y.; Zhang, D. A thermodynamic analysis and economic evaluation of an integrated lignite upgrading and power generation system. Appl. Therm. Eng. 2018, 135, 356-367. [CrossRef]

39. Price Indices of Typical Coals. Available online: http:/ /www.cctd.com.cn/index.php? $m=$ content\&c=index\& $a=$ lists \&catid $=520$ (accessed on 15 August 2018). 